\title{
FAMILY, POVERTY AND CONFLICT IN THE METROPOLITAN CITY OF DOUALA- CAMEROON
}

NANCHE BILLA ROBERT

(Received 15 February 2021, Revision Accepted 28 April 2021)

\begin{abstract}
The objective of this work was to describe how poverty influences family's consumption pattern in the Household wealth theory which explains that wealth is a source of well-being and how the increasing rate of unemployment among household due to the deterioration of the job markets has affected family members' consumption of home products for 202 participants. A systematic sampling method was used in which in every neighbourhood, much effort was made to start with an nth subject and then select every twentieth unit after the first was selected. The questionnaires were administered by directly contacting and handing them to the respondents (self-administered) and the non-literate ones were helped to fill them. It was discovered that, people tend to prefer nuclear family as their income rises and extended family as their income decreases. The nuclear family members have a better consumption habit than extended family members, single parents and single people because they earn more money and have a much smaller family-size. However, single parent tend to significantly use formal health seeking methods than others because they also have smaller families. The extended family consume more homebased goods and therefore have more domestic comfort: they do not only significantly own and rent expensive and quality homes but also have more durable goods.
\end{abstract}

KEYWORDS: Family type, domestic comfort, health seeking behavior, conflict, family size.

\section{INTRODUCTION}

After a period of sustained growth, which Cameroon experienced up to the middle of the 1980s accomplishing an annual average growth of 7 percent over a ten-year period, the situation deteriorated from 1986 onward and the country has suffered a severe economic and social crisis, (Baye 2004). There has been a sharp reversal in economic performance - the prices of cash crops dropped, petroleum income drastically declined. The World Bank estimated the drop to about $60 \%$ in terms of exchange between 1986-1993. This fall in volume reduced the national income three times between 1985-1994. The Gross
Domestic Product per capital declined by 6.3 percent per year from 1985 to 1993 and this translated into a 6 percent rate of decline in private consumption per capita. It led to urban unemployment and the informal sector of the economy grew rapidly. According to Roubaud (1994), the urban unemployment of Cameroon is one of the highest even much higher than those registered in Latin America or in Asia.

Due to Asiatic and Nigerian competition, Cameroon lost both external and internal markets. As solutions, the franc CFA was devalued and salaries were reduced with civil servants being the main victims. The average salary of workers of the administration

Nanche Billa Robert, Department of Anthropology, Sociology and Social Sciences for Development Faculty of Arts, Letters and Social Sciences University of Maroua, Far North Region, PO BOX 644, Republic of Cameroon.

(C) 2021 Bachudo Science Co. Ltd. This work is licensed under Creative Commons Attribution 4.0 International license. 
changed from 134,000 frs CFA to 88,000 frs CFA which was a $35 \%$ reduction. The median salary dropped by $50 \%$. The salaries of the employees of the two other principal sectors (parastatals and the formal private sector) also witnessed salary reduction of about $-20 \%$ less than that of the public sector. The relative stability of the nominal income of the informal sector helped in the reduction of inequality in towns. Equally, the prices of goods and services rose dramatically. Since 1983/84, the economic situation has undergone a deep transformation which has affected households. There was a general growth where people engaged family members in the work market of labour.

The question we ask is: how has Cameroon's regressing economy for the past twenty five years affected families in terms of domestic comfort, health seeking activities, leisure activities as well as feeding habits which are some of the objectives of sustainable development? To what extent has the economic crisis affected families and their children's education? Does the capacity of a family to cope with the crisis depend on family size or a certain family configuration?

The objective of this work was to describe how poverty influences family's well-being matters in the Household wealth theory which explains that wealth is a source of well-being. This paper examines how the increasing rate of unemployment among household due to the deterioration of the job markets has affected family members' participation in the desired leading values of the city of Douala for 202 participants in term of feeding habit, domestic comfort, health seeking behavior, the education which are some of the Sustainable Development Objectives and also to measure the extent to which poverty is the source of conflict at homes.

This work is significant because it explains how poverty has affected families in Cameroon for the past twenty-five years. It is therefore an important work for policy-makers who would want to ameliorate families' living conditions in the metropolitan cities of Cameroon in terms of domestic comfort, healthseeking behavior, feeding habits and their leisure activities.

\section{LITERATURE REVIEW}

Throughout the world, the family has been assigned the responsibility for shielding, protecting, sustaining and otherwise maintaining children. The family provides an important source for entering into intimate, constant, face-to-face contact with other people. Healthy family relationships afford companionship, love, security, a sense of worth, and a general feeling of well-being (Zanden, 1996 page 281).

According to Gardiner, K \& Millar, J. (2006) the risk of poverty is very unevenly distributed in society. Some groups - unemployed people, lone parents, large families, people with disability, and some ethnic groups have much higher poverty rates than average. Some events - losing a job, marital breakdown, having children - also put people at high risk of poverty. But being in a high risk group does not necessarily mean you will be poor, nor experience an event with a high poverty risk attached to it.

During crisis period, families are faced with the constraints of offering jobs to their family members. Since 1983/ the economic situation of Cameroon was profoundly transformed to which household reacted by putting in market family labour. Culliney M., Tina $\mathrm{H}$. \& Stephen M. (2014) say the interlinked with family structures and poverty is the level of economic activity of the adults in the households, with the poverty risk declining as the number of adults in full-time employment in the family increases. At the same time, the nature and extent of these links are continually changing as a result of broader demographic, socioeconomic and policy development. There is still important correlation between hat poverty and insecurity between generations of same family. How does family differences affect people's well-being?

According to Nyanseor S. (2018) the institution of polygyny is not strange to Africans since it was the acceptable form of marriage in Africa prior to the arrival of colonizers and Christianity. It was established to provide a balanced and equal distribution of social, material, security and economic benefits to both women and men and to carter for the sexual, social, psychological and economic needs of unmarried women. It emphasized collective responsibilities, communal ownership of farms, wealth and the economic benefit of the extended family.

According to Polygamy in Africa (2015) Polygny has existed all over the African continent because it represents an aspect of African culture and religion. It is commonly practiced by animist and Muslim communities. African societies have considered children as a form of wealth: a family with more children was considered to be more powerful. It was considered as a way of building an empire. Although South Africa is by far one of the most developed countries in Africa, there are still many traditionalists who practice polygyny, even Jacob Zuma declared that he was a polygynist married to three wives.

Extended-family households are those households that are either multi-generational families, or households containing non- immediate family kins such as aunts, uncles, nieces, nephews and cousins, within the same household. According to Baca Z. \& Eitzen (1993) within the extended-family households "goods, services and emotional support" are often shared and exchanged. Browne, K. (2011) states that extended family groups share a single household to 
enjoy certain advantages such as a greater sense of security and belonging. Members serve as resources and important support system during crisis and feel responsible for helping and supporting one another, both emotionally and financially and are more like role models to help perpetuate desired behavior and cultural values. While contemporary families may be considered more mobile in general than in the past, sociologists find that this has not necessarily resulted in the disintegration of extended family networks. Technological aids such as the Internet and social networking sites such Facebook are presently commonly used to retain contacts and maintain these family ties.

Single-parents households are characterized by a single parent and children. However, a single-parentfamily household does not necessarily mean that only one breadwinner exists within the households, even if the other household members are adolescents. According to Irwin G., Watson D., Sara M. (1986) the growth of the mother-only families is due to economic insecurity of these families - nearly half are poor and most of these are dependent on welfare and are linked to the growth of an underclass which is equated to the feminization of poverty and the emergence of an "underclass" who experienced a large drop in income as a consequence of marital disruption. Just like Amin (2001), Baye (2004) explains that households headed by men are poorer than those headed by women in Cameroon and states that there is no feminisation of poverty in Cameroon.

Culliney M., Tina H. \& Stephen M. (2014) state that families at risk of poverty in Britain include lone parent families, workless households (plus those with only one adult in paid work) and those with three or more children. A greater proportion of lone parents are in the bottom income quintile than any other group. Regardless of their marital status, individuals without children are less likely to be in poverty and also substantially more likely to be in the top quintile.

From the above literature we can formulate the following hypothesis: The poverty of individuals depends on their family configuration. There is a higher probability that members of polygynous and extended family with a greater sense of security, belonging, resources and important support system will suffer less from poverty than single people and single parents.

\section{METHODOLOGY}

\section{SAMPLING DESIGN}

Poverty is relative to a society and epoch. Sociologically speaking, one is poor when one cannot attain the desired values of one's society (Holborn \& Haralambos 1991).
A preliminary survey, or what is often call a pilot survey, was carried out using thirty randomly selected respondents who were asked about the psychological and social essentials for ordinary living patterns in Douala before formulating the questionnaire. One out of every twenty of them was selected. The desired values-things one needs in Douala to live a better life-were obtained from the pilot survey and were grouped into four appropriate categories: domestic comfort, feeding habits, health seeking behavior, and leisure activities. Domestic comfort was broken down into three components:

\section{MEASUREMENT}

The above components were measured in the following ways:

I. homeownership: measured using homeownership, rent, depending on someone, living in a family house, ${ }^{1}$ as well as homelessness, which is perceived in Cameroon as a lack of an abode whether in a poor or rich neighbourhood. (However, there are hardly neighbourhoods exclusively for the poor or rich in Douala. It is easy to identify poor people in rich neighbourhoods and vice versa.)

II. possessions of durable goods: measured using possession of refrigerator, gas cooker, personal cars, computer, etc.

III. home quality: measured using sufficient electrification (having light inside and outside of the compound), having potable water, privacy (keeping one's secrets from one's neighbours), air conditioning, and other qualities of their homes that were mentioned by respondents outside of the abovedesired qualities.

The second category-feeding habits-was broken down into three components. The first two components being variation of food (how often respondents change the type of food they eat) and the taking of a balanced diet (how often they took all the classes of food). These were measured using the following indicators: daily, weekly, fortnightly, and monthly. The third component was the number of times one fed oneself per day which was measured as being once, twice, thrice, and four times.

In health seeking behaviour, respondents were asked where they would go for treatment when they were sick (the hospital, consult a traditional clinic, stay at home, or use all the above). Finally, leisure activities were measured using reading, visiting friends, sport, travelling, visiting recreational centres, watching television, drinking, etc.

The range of salary was established using the minimum and maximum salaries in Cameroon: 23,514 frs and 465,850 frs CFA respectively following 
the trade convention that pays the highest in Cameroon; however, there are workers in Cameroon who earn far above the maximum range and below the minimum range

\section{SAMPLING PROCEDURES}

For the sample population to be representative of the general population, a systematic sampling method was used in which everyone had an equal chance in the selection. In every neighbourhood, much effort was made to start with an nth subject and then select every twentieth unit after the first. In this case every unit in the general population had the same chance of being selected. Questionnaires were administered in all the major neighbourhoods in Douala; the size of the questionnaires administered in each neighbourhood was determined by its size.

The questionnaires were administered by directly contacting and handing them to the respondents (selfadministered) and the non-literate ones were helped to fill them. Since the questionnaire contained some sensitive questions, we ensured that the respondents understood that the research was for an academic purpose. This assurance was conducive to an atmosphere that allowed the respondents to give truthful answers.

Out of the 202 questionnaires administered, fifty-eight were collected by three research assistants: one postgraduate student in Sociology and two graduate students in Psychology who were taught the research methods used. The response rate was representative because care was taken to select respondents from all the neighbourhoods in the city of Douala using the random sampling method.

\section{STATISTICAL ANALYSIS}

We processed our data using the Sphinx software which is a recognised program for analysing data in the social sciences. Particular attention was paid to descriptive and inferential analyses. Each aspect of the operational framework is presented in five stages: display of figures in table, description of the table, interpretation and analysis, inferential analysis by considering aspects like: the chi-test and percentage technique, and finally their sociological implications. In the write-up we compared the specific category to the general population. This method of the calculation of percentage permits one to compare a modality of the independent variable to the percentage obtained in the total population or sample. If the percentage of the independent variable is more than the percentage of the total column we put $a+$. This shows the difference it makes in the whole. In order to show that it is not just random variation the correlation that exists between them was calculated.

\section{FINDINGS AND ANALYSES}

\section{Family Type and Monthly Financial Wealth}

Part of well-being is determined by the ability to meet our material needs and aspirations and therefore depends on income. Of course extreme poverty is an affront to well-being and life satisfaction. Improvised people go hungry, lack safe water and sanitation and cannot access health care when they need it and children die young and tragically (Sachs, 2016). The first objective of the Sustainable Development Objectives is to end extreme poverty in all its forms everywhere in order to ensure that all people are living above the line of poverty. In this part of our work we measure the percentage of families that are above poverty-line.

According to wolff (2008) financial wealth is more of a liquid concept than marketable wealth because it reflects the resources that may be directly available for consumption or various forms of investments in the 
TABLE 1: FAMILY TYPES AND INCOME

\begin{tabular}{|c|c|c|c|c|c|c|c|c|c|}
\hline $\begin{array}{l}\text { Family } \\
\text { Type }\end{array}$ & $\begin{array}{l}\text { Earn } \\
\text { nothing }\end{array}$ & $\begin{array}{l}24,000 \\
74,000\end{array}$ & $\begin{array}{l}75,000 \\
125,000\end{array}$ & $\begin{array}{l}126,000 \\
176,000\end{array}$ & $\begin{array}{l}177,000 \\
227,000\end{array}$ & $\begin{array}{l}228,000 \\
278,000\end{array}$ & $\begin{array}{l}279,000 \\
329,000\end{array}$ & $<330,000$ & Total \\
\hline Dependent & $\begin{array}{l}1 \\
(3.84 \%)\end{array}$ & $\begin{array}{l}1 \\
(1.30 \%)\end{array}$ & $\begin{array}{l}2 \\
(5.12 \%)\end{array}$ & $\begin{array}{l}1 \\
(7.69 \%)\end{array}$ & $\begin{array}{l}0 \\
(0.00 \%)\end{array}$ & $\begin{array}{l}1 \\
(11.11 \%)\end{array}$ & $\begin{array}{l}0 \\
(0.00 \%)\end{array}$ & $\begin{array}{l}1 \\
(7.69 \%)\end{array}$ & $\begin{array}{l}7 \\
(3.46 \%)\end{array}$ \\
\hline Nuclear & $\begin{array}{l}6 \\
(23.07 \%)\end{array}$ & $\begin{array}{l}15 \\
(17.04 \%)\end{array}$ & $\begin{array}{l}6 \\
(15.38 \%)\end{array}$ & $\begin{array}{l}1 \\
(7.69 \%)\end{array}$ & $\begin{array}{l}6 \\
(35.29 \%)\end{array}$ & $\begin{array}{l}2 \\
(22.22 \%)\end{array}$ & $\begin{array}{l}0 \\
(0.00 \%)\end{array}$ & $\begin{array}{l}3 \\
\text { (23.07\%) }\end{array}$ & $\begin{array}{l}39 \\
(19.30 \%)\end{array}$ \\
\hline Extended & $\begin{array}{l}9 \\
(34.61 \%)\end{array}$ & $\begin{array}{l}37 \\
(42.04 \%)\end{array}$ & $\begin{array}{l}17 \\
(43.58 \%)\end{array}$ & $\begin{array}{l}6 \\
\text { (46.15\%) }\end{array}$ & $\begin{array}{l}8 \\
(47.05 \%)\end{array}$ & $\begin{array}{l}6 \\
(66.66 \%)\end{array}$ & $\begin{array}{l}1 \\
(100 \%)\end{array}$ & $\begin{array}{l}5 \\
(38.46 \%)\end{array}$ & $\begin{array}{l}89 \\
(44.06 \%)\end{array}$ \\
\hline Single Parent & $\begin{array}{l}7 \\
(26.92 \%)\end{array}$ & $\begin{array}{l}18 \\
(20.45 \%)\end{array}$ & $\begin{array}{l}9 \\
(23.07 \%)\end{array}$ & $\begin{array}{l}2 \\
(15.38 \%)\end{array}$ & $\begin{array}{l}1 \\
(5.88 \%)\end{array}$ & $\begin{array}{l}0 \\
(0.00 \%) \\
\end{array}$ & $\begin{array}{l}0 \\
(0.00 \%)\end{array}$ & $\begin{array}{l}2 \\
(15.38 \%)\end{array}$ & $\begin{array}{l}39 \\
(19.31 \%)\end{array}$ \\
\hline $\begin{array}{l}\text { Polygnous } \\
\text { family }\end{array}$ & $\begin{array}{l}1 \\
(8.84 \%)\end{array}$ & $\begin{array}{l}4 \\
(4.54 \%)\end{array}$ & $\begin{array}{l}3 \\
(7.69 \%)\end{array}$ & $\begin{array}{l}2 \\
(15.38 \%)\end{array}$ & $\begin{array}{l}1 \\
(5.88 \%)\end{array}$ & $\begin{array}{l}0 \\
(0.00 \%)\end{array}$ & $\begin{array}{l}0 \\
(0.00 \%)\end{array}$ & $\begin{array}{l}1 \\
(7.69 \%)\end{array}$ & $\begin{array}{l}12 \\
(5.94 \%)\end{array}$ \\
\hline Single & $\begin{array}{l}2 \\
(7.69 \%)\end{array}$ & $\begin{array}{l}9 \\
(10.22 \%)\end{array}$ & $\begin{array}{l}2 \\
(5.12 \%) \\
\end{array}$ & $\begin{array}{l}1 \\
(7.69 \%) \\
\end{array}$ & $\begin{array}{l}1 \\
(5.88 \%)\end{array}$ & $\begin{array}{l}0 \\
(0.00 \%) \\
\end{array}$ & $\begin{array}{l}0 \\
(0.00 \%)\end{array}$ & $\begin{array}{l}1 \\
(7.69 \%)\end{array}$ & $\begin{array}{l}16 \\
(7.92 \%)\end{array}$ \\
\hline Total & $\begin{array}{l}26 \\
12.87 \%\end{array}$ & $\begin{array}{l}88 \\
43.56 \%\end{array}$ & $\begin{array}{l}39 \\
19.31 \%\end{array}$ & $\begin{array}{l}13 \\
6.44 \%\end{array}$ & $\begin{array}{l}17 \\
8.42 \%\end{array}$ & $\begin{array}{l}9 \\
4.5 \%\end{array}$ & $\begin{array}{l}1 \\
.5 \%\end{array}$ & $\begin{array}{l}13 \\
6.44 \%\end{array}$ & $\begin{array}{l}202 \\
100 \%\end{array}$ \\
\hline
\end{tabular}

The above table indicates that most persons (44.06\%) are part of an extended family in Douala, the metropolitan city of Cameroon. There are almost the same percentage of those who have nuclear family and single parents: $19.31 \%$ and $19.30 \%$ respectively. Single parents are persons who have children but are not married. However, there are still about 5.94\% polygnous families; that is, men who have more than one wives. About $3.46 \%$ still depend on either parents or family members. These are persons who normally have to be independent but due to economic and social constraints, they are bound to continue living in a family house or under the guardianship of a relative or any other person. There are also about $7.92 \%$ single persons: this group of persons is independent but they neither have children nor husband/wife.

Table 1 indicates that about $43.56 \%$ of the families earn about 25,000 - 75,000frs CFA and about $12.8 \%$ of them earn nothing. According to Nanche R. (2016b) the average income of families in the city of Douala is 103,505 frs CFA which is far below the poverty-line of 177,000 fr CFA. Above $90 \%$ of those who earn above $177,000 \mathrm{frs}$ possess nearly all the durable goods, have healthy feeding habits and health seeking behaviour. They are better-off than those who earn below it.

Therefore, a vast majority of the families in the city of Douala live in poverty because jobs creation in the public service dropped drastically in the public service from $50 \%$ before 1985 to below $10 \%$ in 1992 and it stagnated between $15 \%$ and $20 \%$ from 1985 to 1992 . As such in 1992 more than $80 \%$ of created jobs were in the informal sector as against only $5 \%$ in the public sector and job creation in the public service has been contracting.
Nanche R. (2007a) shows that $19.3 \%$ of the residents of Douala work in the informal sector which is a very precarious sector due to the lack of decent jobs. However, Aerts, J., Denis C, Javier H, Guy de Monchy, \& Francois R. (.2000) show that the economic activities of the women in Cameroon are not marginal because they work an average of 35 hours per week as against 41 hours for men. The inactivity of women is only possible when the other members of the household bring enough resources for the up-keep of the family. In a situation of insufficient resources, women contribute to the household comfort by working in the informal sector: doing petty business.

Table 1 indicates that about $28.57 \%, 28.21 \%$, $22.47 \%, 10.25 \%, 16.67 \%$ and $12.5 \%$ of dependent people, nuclear family, extended family, single parent, polygnous family and single people earn above the poverty-line of $177,000 \mathrm{frs}$ CFA. Dependent people and people who have nuclear family have the highest number of people who earn above the poverty-line and single parents have the highest number of persons who live below the poverty-line (92.31\%). Long M. (2018) holds that female household heads are particularly at risk to shocks because of their greater economic insecurity and maybe likely to use high-cost borrowing to make ends meets.

Although a good number of people in the city of Douala have extended family, those who earn slightly more are those who have nuclear family. Therefore the residents of the city of Douala slightly tend to prefer nuclear family as their income rises and as income decreases people tend to use extended family as a survival means because as Browne K. (2011) states members of extended family enjoy greater 
sense of security, belonging, important support network and resource during a crisis.

However, it is worth noting that the gap between the poverty-line of the various family-types is narrow. Despite all these minor differences, the dependence of income on family is very insignificant (chi2 $=21.85$, $\mathrm{ddl}=35, \mathrm{I}-\mathrm{P}=4,05 \%$ ). Therefore the type of family one has is not influenced by the amount of money one earns.

However despite this insignificant relationship between family type and income, our objective then is to find out the extent to which family type influence one's participation in the predominant values in the city of Douala (feeding habits, domestic comfort, health seeking behavior).

\section{Family Configuration and Consumption of Food}

The second objective of the sustainable Development Objectives is to end hunger, improve nutrition and promote sustainable agriculture. In this section, we examine whether the type of family one has influences ones feeding habit in terms of daily meals frequency, the consumption of variety of meals, consuming a balanced diet, the consumption of enough fruits and vegetables.

According to Savage J., Jennifer O., and Leam B. (2008) during conditions of scarcity, family life and resources are devoted to the procurement and preparation of foods, which are often low in energy, nutrients, and palatability. In sharp contrast, today in non-third world countries children's eating habits develop under unprecedented conditions of dietary abundance, where palatable, inexpensive, ready-toeat foods are readily available.

\section{TABLE 2: FAMILY TYPES AND DAILY MEAL FREQUENCY}

\begin{tabular}{|l|l|l|l|l|l|}
\hline $\begin{array}{l}\text { Meal } \\
\begin{array}{c}\text { Frequensy } \\
\text { Family } \\
\text { Type }\end{array}\end{array}$ & Once & Twice & Thrice & Four times & Total \\
\hline Dependent & 0 & & & & \\
& $(0.00 \%)$ & $(2.04 \%)$ & $\mathbf{( 7 . 0 4 \% )}$ & $\begin{array}{l}(0.00 \%) \\
(3.46 \%)\end{array}$ \\
\hline Nuclear & 2 & 17 & $\mathbf{1 6}$ & $\mathbf{3}$ & 39 \\
& $(\mathbf{8 . 6 9 \% )}$ & $(17.34 \%)$ & $\mathbf{( 2 2 . 5 3 \% )}$ & $\mathbf{( 3 0 . 0 0 \% )}$ & $(19.30 \%)$ \\
\hline Extended & $\mathbf{1 9}$ & 41 & 24 & $\mathbf{5}$ & $\mathbf{8 9}$ \\
& $\mathbf{( 8 2 . 6 0 \% )}$ & $(41.83 \%)$ & $(33.80 \%)$ & $\mathbf{( 5 0 . 0 0 \% )}$ & $(44.06 \%)$ \\
\hline Single Parent & 0 & 24 & 13 & 2 & 39 \\
& $(0.00 \%)$ & $\mathbf{( 2 4 . 4 8 \% )}$ & $(18.30 \%)$ & $(20.00 \%)$ & $(19.31 \%)$ \\
\hline Polygny & 0 & 5 & $\mathbf{7}$ & 0 & 12 \\
& $(0.00 \%)$ & $(5.10 \%)$ & $\mathbf{( 9 . 8 5 \% )}$ & $(0.00 \%)$ & $(5.94 \%)$ \\
\hline Single & $\mathbf{2}$ & $\mathbf{8}$ & $\mathbf{6}$ & 0 & 16 \\
& $(\mathbf{8 . 6 9 \% )}$ & $\mathbf{( 8 . 1 6 \% )}$ & $\mathbf{( 8 . 4 5 \% )}$ & $(0.00 \%)$ & $(7.92 \%)$ \\
\hline Total & 23 & 98 & 71 & 10 & 202 \\
& $11.39 \%$ & $48.5 \%$ & $35.14 \%$ & $5 \%$ & \\
\hline
\end{tabular}

The above table shows that almost half of the families in the city of Douala have poor nutrition because they eat only twice per day. Only about $40.14 \%$ eat three or more times per day because they earn an average income of about $103,505 \mathrm{frs}$ CFA which is far below the poverty-line of $177,000 \mathrm{fr}$ CFA.

People who have nuclear family conspicuously stand out by eating significantly three and four times per day because their family size is relatively smaller than that of extended and polygnous families and they earn higher than the other family types: they have the highest percentage of those who earn above the poverty-line (28.21\%).

Those who have extended family are at extremes because they significantly eat four and one times per day because they significantly have a bigger family size as compared to those having nuclear family. They equally have about $22.47 \%$ of those who earn above the poverty-line, and about $51.7 \%$ of them earn between 0-50,000frs CFA. Therefore the significant number of times those who have extended family eat per day is influenced by what they earn per month.

Although about $16.7 \%$ of people who have polygnous family earn above the poverty-line, they significantly eat three times per day even better than those who have extended family who significantly eat four and one times per day (two extremes).

About $50 \%$ of single people eat twice per day and only $37.5 \%$ eat thrice per day and hardly four times because about $12.5 \%$ of them earn above the 
poverty-line. However, their meal frequency is much better than that of single parents who significantly only eat twice per day (about $61.5 \%$ of them) because only about $7.7 \%$ of them earn above the poverty-line.

Table 2 shows that about $71.42 \%$ of dependent people feed three times per day. This is a group of persons who are working and are still living in family houses or they are unemployed and depend on the family and other extended family members for their livelihood.

Therefore family size has an impact on the frequency of meals consumed per day. Dependent people and those who have nuclear families have the highest percentage of those who earn above the poverty-line and also significantly have those who eat thrice or more times per day. Surprisingly, polygnous family members who have the lowest income significantly eat thrice per day. Single parents are people who suffer the most because they significantly eat once and twice per day. Although there is no relationship between family types and income, the above table shows that meal frequency is very significantly influenced by family type (chi2 $=26.94$, ddl $=15$, I-P $=97.08 \%$ ).

Our research indicates that nearly all the family types consume varieties of meals per day except for those who have extended family and single people. Dependent people and those who have polygnous families seem to be better than the others because they significantly consume varieties of meals daily and fortnightly, followed by single parents who significantly consume it daily and yearly. Those who have nuclear family have all categories of persons who significantly consume varieties of meals daily, monthly, yearly and occasionally, that is whenever they find it. Although people who have extended family do not consume variety of meals daily, they significantly consume it monthly, yearly and occasionally. Those who are hardly hit are single people because they do not significantly eat varieties of meals daily except monthly.

However, the dependence of family type on consuming variety of meal is not significant (chi2=22,82, ddl $=20, \quad I-P=70,22 \%$ ) because what matters is not just consuming a variety of meals but its quality because poor people eat mostly variety of starchy foods and less foods which contain protein and vitamins. That is the reason why we examine whether there is a relationship between family types and the consumption of a balanced diet.

TABLE 3: FAMILY TYPES AND THE FREQUENCY OF CONSUMING A BALANCED DIET

\begin{tabular}{|c|c|c|c|c|c|c|c|}
\hline $\begin{array}{l}\text { Balanced Diet } \\
\text { Frequency } \\
\text { Family } \\
\text { Types }\end{array}$ & $\begin{array}{l}\text { Occasion } \\
\text { ally }\end{array}$ & Daily & Weekly & Fortnightly & Monthly & Yearly & Total \\
\hline Dependent & $\begin{array}{l}1 \\
(14.28 \%)\end{array}$ & $\begin{array}{l}4 \\
(5.63 \%) \\
\end{array}$ & $\begin{array}{l}1 \\
(1.23 \%)\end{array}$ & $\begin{array}{l}0 \\
(0.00 \%) \\
\end{array}$ & $\begin{array}{l}0 \\
(0.00 \%) \\
\end{array}$ & $\begin{array}{l}1 \\
(20.00 \%)\end{array}$ & $\begin{array}{l}7 \\
(3.46 \%) \\
\end{array}$ \\
\hline Nuclear & $\begin{array}{l}1 \\
(14.28 \%)\end{array}$ & $\begin{array}{l}17 \\
(23.94 \%)\end{array}$ & $\begin{array}{l}12 \\
(14.81 \%)\end{array}$ & $\begin{array}{l}5 \\
(19.23 \%)\end{array}$ & $\begin{array}{l}3 \\
(23.07 \%)\end{array}$ & $\begin{array}{l}1 \\
(20.00 \%)\end{array}$ & $\begin{array}{l}39 \\
(19.30 \%)\end{array}$ \\
\hline Extended & $\begin{array}{l}2 \\
(28.57 \%)\end{array}$ & $\begin{array}{l}25 \\
(35.21 \%)\end{array}$ & $\begin{array}{l}42 \\
(51.85 \%)\end{array}$ & $\begin{array}{l}11 \\
(42.30 \%)\end{array}$ & $\begin{array}{l}8 \\
(66.66 \%)\end{array}$ & $\begin{array}{l}1 \\
(20.00 \%)\end{array}$ & $\begin{array}{l}89 \\
(44.06 \%)\end{array}$ \\
\hline Single Parent & $\begin{array}{l}1 \\
(14.28 \%)\end{array}$ & $\begin{array}{l}16 \\
(22.53 \%)\end{array}$ & $\begin{array}{l}19 \\
(23.45 \%)\end{array}$ & $\begin{array}{l}1 \\
(3.84 \%)\end{array}$ & $\begin{array}{l}1 \\
(8.33 \%)\end{array}$ & $\begin{array}{l}1 \\
(0.00 \%)\end{array}$ & $\begin{array}{l}39 \\
(19.31 \%)\end{array}$ \\
\hline $\begin{array}{l}\text { Polygnous } \\
\text { family }\end{array}$ & $\begin{array}{l}2 \\
(28.57 \%)\end{array}$ & $\begin{array}{l}6 \\
(8.45 \%) \\
\end{array}$ & $\begin{array}{l}2 \\
(2.46 \%)\end{array}$ & $\begin{array}{l}2 \\
(7.69 \%)\end{array}$ & $\begin{array}{l}0 \\
(0.00 \%)\end{array}$ & $\begin{array}{l}0 \\
(0.00 \%)\end{array}$ & $\begin{array}{l}12 \\
(5.94 \%)\end{array}$ \\
\hline Single & $\begin{array}{l}0 \\
(0.00 \%)\end{array}$ & $\begin{array}{l}3 \\
(4.22 \%)\end{array}$ & $\begin{array}{l}5 \\
(6.17 \%)\end{array}$ & $\begin{array}{l}7 \\
(26.92 \%)\end{array}$ & $\begin{array}{l}0 \\
(0.00 \%)\end{array}$ & $\begin{array}{l}1 \\
(20.00 \%)\end{array}$ & $\begin{array}{l}16 \\
(7.92 \%)\end{array}$ \\
\hline Total & $\begin{array}{l}7 \\
3.46 \%\end{array}$ & $\begin{array}{l}71 \\
35.15 \%\end{array}$ & $\begin{array}{l}81 \\
40.09 \% \%\end{array}$ & $\begin{array}{l}26 \\
12.87 \%\end{array}$ & $\begin{array}{l}12 \\
5.94 \%\end{array}$ & $\begin{array}{l}5 \\
2.48 \%\end{array}$ & $\begin{array}{l}202 \\
100 \%\end{array}$ \\
\hline
\end{tabular}

The above table still indicates that people having extended family and single persons hardly consume a balanced diet which in this research means a wellgarnished meal containing nearly all the classes of food such as protein, vitamins, carbohydrates, fats and oil etc. People who have extended family significantly consume it weekly and monthly while the single people significantly consume it fortnightly and yearly meaning they suffer the most because of lack of means. 
Although single parents feed themselves significantly twice per day, significantly consume a variety of meals daily and yearly, significantly consume fruits and vegetables weekly and yearly, surprisingly, they significantly take a well-balanced meal daily and weekly. Therefore single parents may not eat many times nor consume a variety of meals nor consume fruits and vegetables but they care to eat well balanced meals.

Although those who are still dependent significantly take a balanced diet daily, another group of them consume it occasionally: when they can find it. Despite the fact that those who have nuclear family consume a balanced diet daily, a significant number of them also consume it monthly and yearly. Although those having polygnous family significantly consume a balanced diet daily, they also significantly consume it twice fortnightly and occasionally.

However, unlike consuming a variety of meals, the dependence of consuming a balanced diet on family type is very significant (chi2 $=47.07, \mathrm{ddl}=25, \mathrm{I}-\mathrm{P}=$ 99.25

\section{TABLE 4: FAMILY TYPES AND FREQUENCY OF EATING ENOUGH FRUITS AND VEGETABLES}

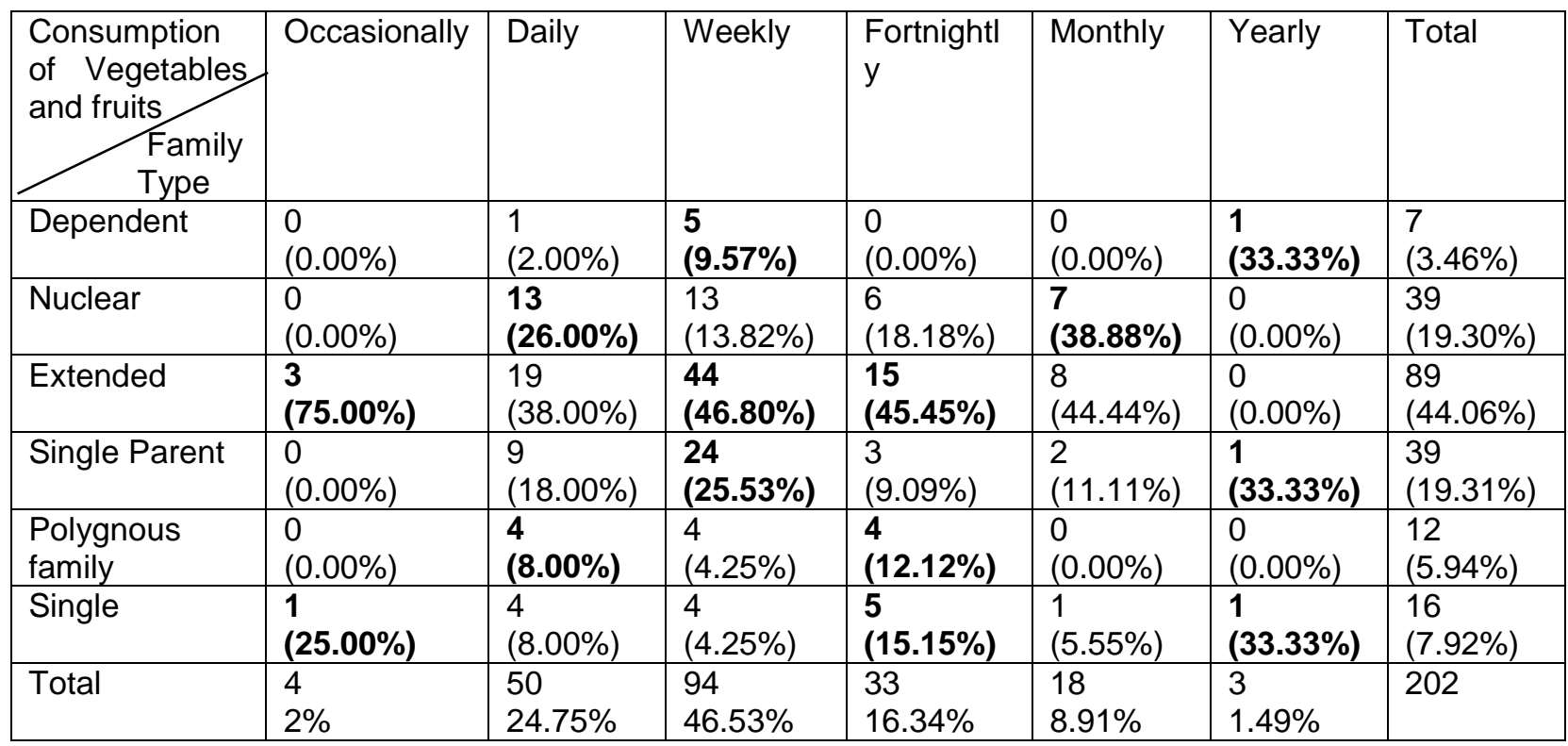

The above table indicates that compared to other marital types, people having nuclear and polygnous families significantly eat enough fruits and vegetables daily and fortnightly and single people eat enough vegetables and fruits fortnightly and yearly. Dependent people significantly eat enough vegetables and fruits only fortnightly and yearly. Single parents also significantly eat it daily and weekly. Extended family and single parents hardly eat enough vegetables and fruits daily. The former significantly eat it fortnightly and occasionally while the later eat it significantly fortnightly and yearly. The dependence of eating enough fruits and vegetables on family type is significant (chi2=38,88, ddl $=25, \mathrm{l}-\mathrm{P}=96,21 \%$ )

Basing on the four aspects which the residents of Douala consider as appropriate feeding habits, we discovered that the nuclear family has a better feeding habit because they significantly eat three to four times per day, consume a variety meal daily, fortnightly and occasionally, take enough fruits and vegetables daily and monthly and a balanced diet daily and monthly.
Equally, polygnous family members who do not earn much have better feeding habits than extended family members and single parents: they feed thrice per day, vary their meals and significantly eat enough vegetables and fruits daily and fortnightly and balanced diet daily, fortnightly and occasionally. Dependent people who earn better than polygnous family do not feed better than them because although they eat thrice per day, significantly vary their meals daily and fortnightly, eat enough fruits and vegetables weekly and yearly and a balanced diet daily and occasionally. Extended family members, single parents and single people have poor feeding habits. Single parents significantly eat twice per day, vary their meals daily and yearly, eat enough fruits and vegetables weekly and yearly and a balanced diet daily and weekly which is better than that of extended family and single people do not significantly consume variety of meals, enough fruits and vegetables and a balanced diet daily. Apart from the variety of meals, 
there is a significant relationship between family type and feeding habits.

\section{Family Types and Health Seeking Behaviour}

Objective three of the Sustainable Development is to ensure healthy lives for all which include the treatment of many kinds of non-communicable diseases. In this section, we try to establish whether there is a correlation between the type of family and health seeking behavior which is influenced by income.

According to Phipps Su Ann (1991) the family provides the most significant arena in which health and illness behavours are taught, where treatment is rendered and where illness is resolved. The family furnishes the majority of health care to its members $75 \%$ to $80 \%$ of all health care is provided by self or family regardless of an individual's access to professional health services. It is the family which decides to enlist the assistance of and thus invest financial resources in the health-care delivery system.
In this manner, the family initiates and coordinates professional health care services.

Pierre B., Yves G. (2013) state that the gradient in health reflects a greater prevalence of chronic conditions among low-income children and a greater severity of these conditions. They conclude that income does not matter for a child health in the UK and may play a role in the intergenerational transmission of socioeconomic status.

According to Deaton A. (2013) epidemiologists argue that socioeconomic status is a fundamental cause of health. They frequently endorse measures to improve health through manipulating socioeconomic status, not only by improving education but also by increasing or redistributing incomes. Emerson E., Hilary G., Chris $\mathrm{H}$. (2006) states that the experience of socioeconomic disadvantage and poverty in childhood is associated with impaired development and poorer health status in childhood and increased mortality and morbidity in adulthood.

\section{TABLE 5: FAMILY TYPES AND PLACE OF TREATMENT WHEN SICK}

\begin{tabular}{|c|c|c|c|c|c|}
\hline $\begin{array}{l}\text { Areas of } \\
\text { treatment }\end{array}$ & Hospital & $\begin{array}{l}\text { Traditional } \\
\text { medicine }\end{array}$ & Stay at home & All above & Total \\
\hline Dependent & $\begin{array}{l}5 \\
(3.59 \%)\end{array}$ & $\begin{array}{l}1 \\
(2.77 \%)\end{array}$ & $\begin{array}{l}1 \\
(0.02 .560 \%)\end{array}$ & $\begin{array}{l}0 \\
(0.00 \%)\end{array}$ & $\begin{array}{l}7 \\
(3.46 \%)\end{array}$ \\
\hline Nuclear & $\begin{array}{l}24 \\
(17.26 \%)\end{array}$ & $\begin{array}{l}9 \\
(25.00 \%)\end{array}$ & $\begin{array}{l}11 \\
(28.20 \%)\end{array}$ & $\begin{array}{l}2 \\
(15.38 \%)\end{array}$ & $\begin{array}{l}39 \\
(19.30 \%)\end{array}$ \\
\hline Extended & $\begin{array}{l}62 \\
(44.60 \%)\end{array}$ & $\begin{array}{l}16 \\
(44.44 \%)\end{array}$ & $\begin{array}{l}16 \\
(41.02 \%)\end{array}$ & $\begin{array}{l}7 \\
(53.84 \%)\end{array}$ & $\begin{array}{l}89 \\
(44.06 \%)\end{array}$ \\
\hline Single Parent & $\begin{array}{l}32 \\
(23.02 \%)\end{array}$ & $\begin{array}{l}2 \\
(5.55 \%)\end{array}$ & $\begin{array}{l}5 \\
(12.82 \%)\end{array}$ & $\begin{array}{l}2 \\
(15.38 \%)\end{array}$ & $\begin{array}{l}39 \\
(19.31 \%)\end{array}$ \\
\hline Polygnous family & $\begin{array}{l}7 \\
(5.03 \%) \\
\end{array}$ & $\begin{array}{l}3 \\
(8.33 \%) \\
\end{array}$ & $\begin{array}{l}3 \\
(7.69 \%) \\
\end{array}$ & $\begin{array}{l}1 \\
(7.69 \%) \\
\end{array}$ & $\begin{array}{l}12 \\
(5.94 \%)\end{array}$ \\
\hline Single & $\begin{array}{l}9 \\
(6.47 \%)\end{array}$ & $\begin{array}{l}5 \\
(13.88 \%)\end{array}$ & $\begin{array}{l}3 \\
(7.69 \%)\end{array}$ & $\begin{array}{l}1 \\
(7.69 \%)\end{array}$ & $\begin{array}{l}16 \\
(7.92 \%)\end{array}$ \\
\hline Total & $\begin{array}{l}139 \\
68.8 \% \\
\end{array}$ & $\begin{array}{l}36 \\
17.82 \% \\
\end{array}$ & $\begin{array}{l}39 \\
19.30 \% \\
\end{array}$ & $\begin{array}{l}13 \\
6.43 \% \\
\end{array}$ & $\begin{array}{l}202 \\
100 \% \\
\end{array}$ \\
\hline
\end{tabular}

The above table shows that about $68.8 \%$ of families in the city of Douala go to the hospital when they are sick while $17.82 \%$ use traditional medicine because it is cheaper and more available than pharmaceutical drugs and $19.30 \%$ stay at home when they are sick because of lack of means to go to the hospital and to buy traditional drugs. Most often about $6.43 \%$ will first of all stay at home and when the illness is getting worse, they use traditional medicines and if it does not get better, they will then go to the hospital. They end up using the three methods.

It is visible from the above table that those who are still dependent and single parents have better healthcare than the others because they significantly go to the hospital where their ailments can be better diagnosed contrarily to the findings of Milanie $\mathrm{L}$. (2018) that households that are financially fragile are more vulnerable to unpredictable shocks such as medical bills. Single people use significantly traditional method to treat their illness. Those who significantly stay at home and use traditional methods to cure themselves when they are sick are those who have nuclear families. Those having extended families use all the methods: that is to say when they are sick they stay at home and may use drugs sold by drug dealers and also traditional methods but when the illness 
persists, they then use the formal treatment of illness which is the hospital. It is interesting to note that polygamous family members use significantly the traditional method, stay at home and also use all the other methods.

Those who have smaller family sizes such as dependent people and single parent tend to significantly use formal methods of treatment of illnesses while families with large family size tend to use other methods except the nuclear family. Polynynous and extended families are very unstable in their health seeking behavior because they significantly use all the methods. The above shows that there is a very significant dependence of health seeking behavior on family type (chi2 $=39,31$, ddl $=20$ , I-P =99,39\%)

\section{FAMILY TYPES AND DOMESTIC COMFORT}

In this section, we establish the relationship that exists between family types and homeownership, amount paid as rent, cost of home, and qualities of home and possession of durable goods which are all influenced by family's income.

TABLE 6: FAMILY TYPES AND HOME OWNERSHIP

\begin{tabular}{|c|c|c|c|c|c|c|}
\hline $\begin{array}{l}\text { Homeownership } \\
\text { Family Type }\end{array}$ & Homeless & $\begin{array}{l}\text { Own } \\
\text { home }\end{array}$ & Rent & $\begin{array}{l}\text { Living with } \\
\text { someone }\end{array}$ & $\begin{array}{l}\text { family } \\
\text { house }\end{array}$ & Total \\
\hline Dependent & $\begin{array}{c}0 \\
(0.00 \%)\end{array}$ & $\begin{array}{l}2 \\
(4.00 \%)\end{array}$ & $\begin{array}{l}5 \\
(4.34 \%) \\
\end{array}$ & $\begin{array}{l}0 \\
(0.00 \%)\end{array}$ & $\begin{array}{l}0 \\
(0.00 \%)\end{array}$ & $\begin{array}{l}7 \\
(3.46 \%)\end{array}$ \\
\hline Nuclear & $\begin{array}{l}0 \\
(0.00 \%)\end{array}$ & $\begin{array}{l}13 \\
(26.00 \%)\end{array}$ & $\begin{array}{l}22 \\
(19.13 \%)\end{array}$ & $\begin{array}{l}3 \\
(10 \%)\end{array}$ & $\begin{array}{l}1 \\
(20.00 \%)\end{array}$ & $\begin{array}{l}39 \\
(19.30 \%)\end{array}$ \\
\hline Extended & $\begin{array}{l}0 \\
(0.00 \%)\end{array}$ & $\begin{array}{l}27 \\
(54.00 \%)\end{array}$ & $\begin{array}{l}54 \\
(46.95 \%)\end{array}$ & $\begin{array}{l}7 \\
(23.33 \%)\end{array}$ & $\begin{array}{l}1 \\
(20.00 \%)\end{array}$ & $\begin{array}{l}89 \\
(44.06 \%)\end{array}$ \\
\hline Single Parent & $\begin{array}{l}1 \\
(50.00 \%)\end{array}$ & $\begin{array}{l}5 \\
(10.00 \%)\end{array}$ & $\begin{array}{l}20 \\
(17.39 \%)\end{array}$ & $\begin{array}{l}11 \\
(36.66 \%)\end{array}$ & $\begin{array}{l}2 \\
(40.00 \%)\end{array}$ & $\begin{array}{l}39 \\
(19.31 \%)\end{array}$ \\
\hline $\begin{array}{l}\text { Polygnous } \\
\text { family }\end{array}$ & $\begin{array}{l}0 \\
(0.00 \%)\end{array}$ & $\begin{array}{l}3 \\
(6.00 \%)\end{array}$ & $\begin{array}{l}5 \\
(4.34 \%)\end{array}$ & $\begin{array}{l}4 \\
(13.33 \%)\end{array}$ & $\begin{array}{l}0 \\
(0.00 \%)\end{array}$ & $\begin{array}{l}12 \\
(5.94 \%)\end{array}$ \\
\hline Single & $\begin{array}{l}1 \\
(50.00 \%)\end{array}$ & $\begin{array}{l}1 \\
(2.00 \%)\end{array}$ & $\begin{array}{l}9 \\
(7.82 \%)\end{array}$ & $\begin{array}{l}5 \\
(16.67 \%)\end{array}$ & $\begin{array}{l}1 \\
(20.00 \%)\end{array}$ & $\begin{array}{l}16 \\
(7.92 \%)\end{array}$ \\
\hline Total & $\begin{array}{l}2 \\
1 \%\end{array}$ & $\begin{array}{l}50 \\
24.75 \%\end{array}$ & $\begin{array}{l}115 \\
56.93 \%\end{array}$ & $\begin{array}{l}30 \\
14.85 \%\end{array}$ & $\begin{array}{l}5.47 \% \\
2.4 \%\end{array}$ & 202 \\
\hline
\end{tabular}

About $56.9 \%$ of the people of Douala rent and they are predominantly those who have extended family and the dependent. It is surprising none of dependent people are homeless. Furthermore those who have nuclear and extended family hardly are homeless. This is because those who have nuclear family are relatively richer than the other family types and those from extended family receive help from other family members. However, they can be categorized into three groups:

The first category is made up of dependent people and people with extended family because they are more comfortable than the others. They significantly own homes and also rent certainly because of external security which members of the other family type lack. They are not significantly homeless, do not live under someone nor in a family house.

The second category is made up of people having nuclear and polygnous families. They significantly own homes and also significantly live in a family house and under someone respectively. Their situation is worseup than the first group because they significantly have dependent people.
The last category is made up of those who suffer the most: single parents and single people who are significantly homeless people, that is, people who do not have an abode and also significantly live under someone and in a family house because they have a majority of those who earn below the poverty-line although a significant number of single parents take a balanced diet daily and have good health care.

There is a significant dependence of family types and home ownership (chi2 $=41,29$, ddl $=25$, I-P $=$ $97,86 \%)$

As concern family type and cost of home, we obtained the following results: About $71.4 \%, 66.66 \%, 68.54 \%$, $\mathbf{8 7 . 1 8} \%, 75 \%, \mathbf{1 0 0 \%}$ of dependent people, those who have nuclear, extended families, single parent, polynous family and single people owned homes below two million francs CFA. This indicates that the cheapest houses are owned by single parents, single people, those who have polygnous family and dependent people. Unlike the other types of families, dependent people hardly own homes above 2 million frs CFA. 
About $0 \%, 12.8 \%, 8.2 \%, 8 \%, 8.3 \%, 0 \%$ of dependent people, those who have nuclear, extended families, single parent, polynous family and single people owned homes 2.1 millions to 4.1 millions frs CFA. This shows that dependent people and single people hardly own homes between 2.1 millions to 4.1 millions frs CFA.

About $14.3 \%, 5.12 \%, 12.4 \%, 2.56 \%, 0 \%, 0 \% 4,2$ own homes between 4.2 million and 6,2 millions frs CFA; Those who have polynous family and single people hardly own homes which cost such amount.

Only $3 \%$ and $3.4 \%$ of those who have nuclear and extended family respectively own homes worth 6.3 million and 8.3 millions. The other family types own homes of such worth. Only $1.12 \%$ of extended family practitioners own homes between 8.4millions and10.4 millions.

About $10.3 \%, 5.62 \%$ and $8.33 \%$ of those who have nuclear, extended and polynous families respectively own the most expensive homes in Douala. Although those who have nuclear family dominant in having the most expensive homes, those who have extended family seem to have domestic comfort the more because they appear in all the top categories than those who have nuclear family. Those who own the cheapest homes are single and dependent people.

However, the dependence of family type on cost of home is not significant (chi2 $=28,93$, ddl $=30, \mathrm{I}-\mathrm{P}=$ $47,87 \%)$

\section{FAMILY TYPES AND COST OF RENT.}

About 45.04\%, 19.30\%, 19.80\%, 11.4\%, 3.5\%, 0.05\% of those who live in Douala pay rent less than 20000, 21000-41000, 42000-62000, 63000-73000, 7400094000 frs and more than 115000 frs CFA respectively. The higher the rent, the fewer the number of persons who pay it, and the lower the rent, the higher the number of persons who pay it. This shows that about $45.04 \%$ pay rent below 20,000frs CFA which signifies that a majority of the population live in some of the worst-off houses in the city which lack most basic necessities as shown below in family type and home qualities.

As concerned family types and rent, we obtained the following result $28.6 \%, 46.2 \% 40.45 \%, 51.3 \%$, $58.33 \%, 50 \%$ of those who are dependent, who have nuclear, extended families, who are single parents and have polygnous families as well as single people respectively pay rent below 20,000 frs CFA. Nearly all the family types suffer severely from paying the lowest amount of money as rent with single people topping all the other family types. Dependent people have the lowest because majority of them are still students and are living with their parents.

About $28.6 \%, 23.1 \%, 18 \%, 18 \%$, and $8.33 \% 25 \%$ of those who are dependent, who have nuclear, extended families, who are single parents and have polygnous families as well as single people respectively pay rent between $21000-41,000$ frs CFA per month. It is clear here that dependent and single people rent slightly rent houses of this category which are not the best of houses and have very few homequalities.

About 14.3\%, 23.1\%, 20.22\%, 15.4\%, 33.33\% and $12.5 \%$ of those who are dependent, who have nuclear, extended families, who are single parents and have polygnous families as well as single people respectively pay rent between 42,000-62,000frs CFA. Those who have polygnous families tend to have more houses in this category than the other family types. Those who suffer the most here are dependent and single people. Around 14.3\%, 5.13\%, 16.9\%, $10.3 \%, 0 \%$, and $6.25 \%$ of those who are dependent, who have nuclear, extended families, who are single parents and have polygnous families as well as single people respectively pay rent between 63,000 and 73,000frs CFA per month. The above show that those who have extended families rent expensive houses and polygynous families hardly rent such expensive houses.

Roughly $14.7 \%, 2.56 \%, 3.37 \%, 2.56 \%, 0 \%, 6.25 \%$ of those who are dependent, who have nuclear, extended families, who are single parents and have polygnous families as well as single people respectively pay rent between $74000-94000$ per month. Dependent people clearly stand out here. They certainly rent the most expensive houses in Douala.

Only $1.12 \%$ of polygnous pay rent above $95,000 \mathrm{frs}$ CFA and other family types hardly pay this sum as rent. This means that there are some polygnous families who are extremely rich.

Despite all the differences given above, they are just random variation because the dependence of the amount someone pays as rent on family type is not at all significant (chi2 $=20,01$, ddl $=30, I-P=8,38 \%$ )

\section{FAMILY TYPES AND HOME QUALITIES.}

Although those who have extended family do not significantly possess well-built and secured houses as well as modern toilets, their homes significantly possess five of the given qualities such as potable water, good electrification, not near stagnant water, are not wetted, and are air-conditioned.

Those who have nuclear family and single people's homes significantly possess four of the home qualities except potable water, not near stagnant water and private toilet and single people's homes are not significantly electrified, not near stagnant water and private toilet. It therefore means that both the homes of those who have nuclear family and single people have homes near stagnant water. 
Those who have polygamous family significantly possess just three of the home qualities that is: Wellbuilt and secured homes, potable water and airconditioned houses. Those who have the worst-off houses are single parents who significantly only possess well-built and secured houses and modern toilets.

Therefore, those who have extended family and are dependent do not significantly possess well-built and secured houses and those who have nuclear family and single parents do not significantly possess potable water. Single parents, single people and those who have polygamous family do not significantly possess well-electrified homes.

Nearly all the family type except those who have extended family have homes near stagnant water. Dependent people and single parents do not significantly possess air-conditioned homes. Although dependent people, single parent, single people and those who have nuclear family have modern toilet, they are not significantly private.

Although there are some differences between family and the qualities of homes, they are not significant at all (chi2 $=18,14, \mathrm{ddl}=35, \mathrm{I}-\mathrm{P}=0,83 \%$ ) because of the scarcity of decent houses in the city of Douala. People rent houses not because they want them but because they are unable to find houses that reflect their taste.

\section{FAMILY TYPES AND THE CONSUMPTION OF DURABLE GOODS.}

According to Eurostat (2010), durable goods by their nature tend to last and can be used repeatedly, providing consumers with a flow of services over a number of years. Their long lasting nature means that they have some of the attributes of assets. For households the decisions to purchase a durable good is similar to that of a firm making an investment decision. Consumers weigh the costs of an additional durable against the benefits from the flow of services derived from the good. A key implication is that the rate of change of household's purchases of durable goods is likely to experience wider swings than the growth rate of their purchases of non-durable goods and services. For example a drop in expected lifetime income should prompt households to moderate their consumption. While households adjust to the new conditions, consumption growth falls temporarily.

\section{TABLE 7: FAMILY TYPES AND THE POSSESSION OF DURABLE GOODS}

\begin{tabular}{|c|c|c|c|c|c|c|c|c|}
\hline $\begin{array}{c}\text { Durable } \\
\text { Goods } \\
\text { Family } \\
\text { Type }\end{array}$ & $\begin{array}{l}\text { Refrig } \\
\text { erator }\end{array}$ & Cooker & Radio & $\begin{array}{l}\text { Televisi } \\
\text { on }\end{array}$ & $\begin{array}{l}\text { Persona } \\
\text { I car }\end{array}$ & $\begin{array}{l}\text { Comput } \\
\text { er }\end{array}$ & $\begin{array}{l}\text { Telepho } \\
\text { ne }\end{array}$ & Total \\
\hline Dependent & $\begin{array}{l}4 \\
3.92 \%\end{array}$ & $\begin{array}{l}5 \\
4.13 \%\end{array}$ & $\begin{array}{l}6 \\
3.7 \%\end{array}$ & $\begin{array}{l}7 \\
4.7 \%\end{array}$ & $\begin{array}{l}2 \\
5.9 \%\end{array}$ & $\begin{array}{l}2 \\
5.3 \%\end{array}$ & $\begin{array}{l}4 \\
3 \%\end{array}$ & $\begin{array}{l}7 \\
(3.46 \%)\end{array}$ \\
\hline Nuclear & $\begin{array}{l}17 \\
16.66 \\
\%\end{array}$ & $\begin{array}{l}22 \\
8.18 \%\end{array}$ & $\begin{array}{l}31 \\
19 \%\end{array}$ & $\begin{array}{l}31 \\
18.45 \%\end{array}$ & $\begin{array}{l}83.52 \% \\
\end{array}$ & $\begin{array}{l}7 \\
18.42 \%\end{array}$ & $\begin{array}{l}26 \\
19.54 \%\end{array}$ & $\begin{array}{l}39 \\
(19.30 \%)\end{array}$ \\
\hline Extended & $\begin{array}{l}52 \\
50.98 \\
\%\end{array}$ & $\begin{array}{l}58 \\
47.93 \%\end{array}$ & $\begin{array}{l}79 \\
48.46 \\
\%\end{array}$ & $\begin{array}{l}78 \\
46.42 \%\end{array}$ & $\begin{array}{l}18 \\
52 \%\end{array}$ & $\begin{array}{l}21 \\
55.26 \%\end{array}$ & $\begin{array}{l}59 \\
44.36 \%\end{array}$ & $\begin{array}{l}89 \\
(44.06 \%)\end{array}$ \\
\hline Single Parent & $\begin{array}{l}19 \\
18.63 \\
\%\end{array}$ & $\begin{array}{l}22 \\
18.48 \%\end{array}$ & $\begin{array}{l}27 \\
16.56 \\
\%\end{array}$ & $\begin{array}{l}30 \\
17.86 \%\end{array}$ & $\begin{array}{l}3 \\
8.8 \%\end{array}$ & $\begin{array}{l}4 \\
10.53 \%\end{array}$ & $\begin{array}{l}25 \\
18.8 \%\end{array}$ & $\begin{array}{l}39 \\
(19.31 \%)\end{array}$ \\
\hline $\begin{array}{l}\text { Polygnous } \\
\text { family }\end{array}$ & $\begin{array}{l}5 \\
4.90 \%\end{array}$ & $\begin{array}{l}5 \\
4.13 \%\end{array}$ & $\begin{array}{l}8 \\
4.9 \%\end{array}$ & $\begin{array}{l}9 \\
5.36 \%\end{array}$ & $\begin{array}{l}3 \\
8.8 \%\end{array}$ & $\begin{array}{l}1 \\
2.63 \%\end{array}$ & $\begin{array}{l}8 \\
6.02 \%\end{array}$ & $\begin{array}{l}12 \\
(5.94 \%)\end{array}$ \\
\hline Single & $\begin{array}{l}5 \\
4.90 \%\end{array}$ & $\begin{array}{l}9 \\
7.4 \%\end{array}$ & $\begin{array}{l}12 \\
7.36 \%\end{array}$ & $\begin{array}{l}13 \\
7.73 \%\end{array}$ & 0 & $\begin{array}{l}3 \\
7.89 \% \\
\end{array}$ & $\begin{array}{l}11 \\
8.27 \%\end{array}$ & $\begin{array}{l}16 \\
(7.92 \%)\end{array}$ \\
\hline Total & $\begin{array}{l}102 \\
50.9 \%\end{array}$ & $\begin{array}{l}121 \\
59.90 \%\end{array}$ & $\begin{array}{l}163 \\
80.69 \\
\% \\
\end{array}$ & $\begin{array}{l}168 \\
83.17 \%\end{array}$ & $\begin{array}{l}34 \\
16.83 \%\end{array}$ & $\begin{array}{l}38 \\
18.81 \%\end{array}$ & $\begin{array}{l}133 \\
65.84 \%\end{array}$ & 202 \\
\hline
\end{tabular}

According to Wolff E. (2008) consumer durables such as automobile, television, furniture, household appliances and the like provide consumption services directly to the household. For example the average value of auto owned by households in America was
17,350 dollars which equaled 3.3 percent of total assets (including the value of auto)

The above table indicates that people with extended families significantly possess all the durable goods especially more expensive durable goods such as 
refrigerators and personal where more than $50 \%$ of those who possess them have extended family. They are followed by those who are dependent because they live in houses which possess them and not necessary that they bought them themselves.

Those who have polygnous family make a slight significance in possessing a personal car and a telephone. Those who have nuclear family significantly possess a personal car and a telephone. Single people significantly possess only a telephone. Those who suffer the most are single parents because they do not significantly possess any of the above durable goods.

The above table shows that $50.9 \%, 59.90 \%, 80.69 \%$, $83.17 \%, 16.83 \%, 18.81 \%, 65.84 \%$ of the population of Douala possess a refrigerator; cooker, radio, television, personal car, computer and a telephone respectively. Apart from possessing a radio and television which are very cheap, only very few residents of Douala possess the other durable goods. Just as home qualities, those who earn between 24,000-74,000frs CFA significantly possess none of the durable goods. Those who earn between 75,000125,000 frs CFA are a bit better-up than those who earn between 24,000-74,000frs CFA because they significantly possess refrigerator and radio. Although, those who earn between 126,000-176,000frs CFA are much better than those who earn below them, they do not significantly have personal car and computer. Apart from some exceptions, those who earn above 177,000 frs CFA significantly own all the desired durable goods. The dependence of possession of durable goods on income is significant (chi2=67.88, ddl $=49, \mathrm{I}-\mathrm{p}=>96.17 \%$ )
The extended family enjoy more domestic comfort than the other family types: they do not only significantly own and rent expensive and quality homes but also have more durable goods. They hardly own homes near stagnant water. Next to them are those who have nuclear families who equally significantly own and rent expensive homes but their homes have fewer qualities as compared to that of the members of extended family and they possess very limited durable goods. Although dependent people hardly own and rent expensive homes, they have more durable goods and high quality homes because they depend on others. Polygnous families own and rent averagely expensive houses and their homes are not of high quality and they possess very limited number of durable goods.

Those who suffer the most are single people and single parents. However, single people slightly have more domestic comfort than single parents: they own and rent better houses than those of single parents and they significantly possess few or no durable goods.

\section{NUMBER OF CHILDREN AND EDUCATION.}

There is no culture of poverty in Cameroon because one's parent's occupation does not determine one's level of poverty. There is just no relation between parent's occupation and the type of house one has, it's worth, how much one pays as rent, possession of durable goods and one's incomes. Therefore in Douala one can make it no matter the type of family one comes from; provided one works harder.

\section{TABLE 8: FAMILY TYPES AND NUMBER OF CHILDREN}

\begin{tabular}{|l|l|l|l|l|l|l|}
\hline \multicolumn{1}{r|}{$\begin{array}{c}\text { Family } \\
\text { Type }\end{array}$} & 0 & $1-3$ & $4-6$ & $7-9$ & $10-12$ & Total \\
\hline Dependent & 2 & & & & \\
& $(6.66 \%)$ & $(1.96 \%)$ & $(0.00 \%)$ & $\begin{array}{l}(0.00 \%) \\
(50.00 \%)\end{array}$ & $(3.46 \%)$ \\
\hline Nuclear & 11 & 19 & 5 & 0 & 0 & 39 \\
& $(36.66 \%)$ & $(18.62 \%)$ & $(17.85 \%)$ & $(0.00 \%)$ & $(0.00 \%)$ & $(19.30 \%)$ \\
\hline Extended & 12 & 44 & 19 & 6 & 0 & 89 \\
& $(40.00 \%)$ & $(43.13 \%)$ & $(67.85 \%)$ & $(100.00 \%)$ & $(0.00 \%)$ & $(44.06 \%)$ \\
\hline Single Parent & 3 & 34 & 2 & 0 & 0 & 39 \\
& $(10.00 \%)$ & $(33.33 \%)$ & $(7.14 \%)$ & $(0.00 \%)$ & & $(19.31 \%)$ \\
\hline Polygnous family & 2 & 3 & 2 & 0 & 1 & 12 \\
& $(6.66 \%)$ & $(2.94 \%)$ & $(7.14 \%)$ & $(0.00 \%)$ & $(50.00 \%)$ & $(5.94 \%)$ \\
\hline Single & 0 & 0 & 0 & 0 & 0 & 16 \\
& $(0.00 \%)$ & $(0.00 \%)$ & $(0.00 \%)$ & $(0.00 \%)$ & $(0.00 \%)$ & $(7.92 \%)$ \\
\hline Total & 30 & 102 & 28 & 6 & 2 & 202 \\
& $14.85 \%$ & $50.5 \%$ & $13.86 \%$ & $2.97 \%$ & $1 \%$ & \\
\hline
\end{tabular}


The above table shows that $14.9 \%, 50.5 \%, 13.9 \%$, $3 \%$, and $1 \%$ have no children, one to three, four to six, seven to nine and ten to twelve children respectively. Those who are dependent and have nuclear family significantly have no children because of financial reason and also significantly have 7-9 children. The later are people who are older and are on retirement so they are depending on their children for survival. Those who have polygnous family also significantly have no children certainly reason why they got a second wife in order to get them a child and they also significantly have four to six children.

Single parents significantly have between one to three children which most of them are not through any legal relationship. However, those who have nuclear family, single people, and younger dependent people significantly have no children.

There is a very significant relationship between number of children and types of family (chi2 $=146,74$, $\mathrm{ddl}=25, \mathrm{I}-\mathrm{P}=99,99 \%$ ) Therefore if one is a younger dependent or single person, have a nuclear or polygnous family, there is the likelihood that one significantly has no children and there is a relationship between being an older dependent person, having an extended or polygnous family and having around four to nine

\section{TABLE 9: FAMILY TYPES AND THE TYPES OF SCHOOL CHILDREN ATTEND}

\begin{tabular}{|c|c|c|c|c|c|c|}
\hline $\begin{array}{c}\text { Types } \\
\text { Family } \\
\text { Types }\end{array}$ & $\begin{array}{l}\text { Government } \\
\text { School }\end{array}$ & $\begin{array}{l}\text { Lay Private } \\
\text { School }\end{array}$ & $\begin{array}{l}\text { Mission } \\
\text { School }\end{array}$ & $\begin{array}{l}\text { Prestigious } \\
\text { Private } \\
\text { School }\end{array}$ & missing & Total \\
\hline Dependent & $\begin{array}{l}4 \\
(7.69 \%)\end{array}$ & $\begin{array}{l}1 \\
(1.21 \%)\end{array}$ & $\begin{array}{l}2 \\
(5.40 \%)\end{array}$ & $\begin{array}{l}0 \\
(0.00 \%)\end{array}$ & 0 & $\begin{array}{l}7 \\
(3.46 \%) \\
\end{array}$ \\
\hline Nuclear & $\begin{array}{l}13 \\
(25 \%)\end{array}$ & $\begin{array}{l}16 \\
(19.51 \%)\end{array}$ & $\begin{array}{l}8 \\
(21.62 \%)\end{array}$ & $\begin{array}{l}2 \\
(13.33 \%)\end{array}$ & 0 & $\begin{array}{l}39 \\
(19.30 \%)\end{array}$ \\
\hline Extended & $\begin{array}{l}25 \\
(48.07 \%)\end{array}$ & $\begin{array}{l}44 \\
(53.65 \%)\end{array}$ & $\begin{array}{l}15 \\
(40.54 \%)\end{array}$ & $\begin{array}{l}5 \\
(33.33 \%)\end{array}$ & 0 & $\begin{array}{l}89 \\
(44.06 \%)\end{array}$ \\
\hline Single Parent & $\begin{array}{l}20 \\
(38.5 \%)\end{array}$ & $\begin{array}{l}17 \\
(20.73 \%)\end{array}$ & $\begin{array}{l}10 \\
(27.02 \%)\end{array}$ & $\begin{array}{l}8 \\
(53.33 \%)\end{array}$ & 0 & $\begin{array}{l}39 \\
(19.31 \%)\end{array}$ \\
\hline $\begin{array}{l}\text { Polygnous } \\
\text { family }\end{array}$ & $\begin{array}{l}6 \\
(11.53 \%)\end{array}$ & $\begin{array}{l}4 \\
(4.87 \%) \\
\end{array}$ & $\begin{array}{l}2 \\
(5.40 \%)\end{array}$ & $\begin{array}{l}0 \\
(0.00 \%)\end{array}$ & 0 & $\begin{array}{l}12 \\
(5.94 \%) \\
\end{array}$ \\
\hline Single & $\begin{array}{l}16 \\
(23.52 \%)\end{array}$ & $\begin{array}{l}0 \\
(0.00 \%)\end{array}$ & $\begin{array}{l}0 \\
(0.00 \%)\end{array}$ & $\begin{array}{l}0 \\
(0.00 \%)\end{array}$ & 16 & $\begin{array}{l}16 \\
(7.92 \%)\end{array}$ \\
\hline Total & $\begin{array}{l}52 \\
25.74 \%\end{array}$ & $\begin{array}{l}82 \\
40.6 \%\end{array}$ & $\begin{array}{l}37 \\
18.3 \%\end{array}$ & $\begin{array}{l}15 \\
7.4 \%\end{array}$ & $\begin{array}{l}16 \\
7.92 \% \\
\end{array}$ & $\begin{array}{l}202 \\
100 \%\end{array}$ \\
\hline
\end{tabular}

The above table indicates that $25.74 \%, 40.6 \%, 18.3 \%$, and $7.4 \%$ of families in the city of Douala send their children to government school, lay private school, mission school and prestigious school. Therefore, more parents send their children to lay private schools because of the lot of constraints involved in sending their children to public schools: they are often required to pay some money before their children are admitted although no fees is paid in such school.

Children of dependent people significantly attend public and mission school while those of the nuclear family significantly go to mission school. The children of those who have extended family significantly attend lay private schools. The children of single parents significantly attend lay private school, mission and prestigious private school while those of polygnous family attend public schools. Only single parents significantly send their children to prestigious private schools.

The analyses show that where children go to school is influenced by the family size. Family which have large family sizes like the families of older dependent persons and extended families as well as polygnous families children go to either government school which is cheaper or free and lay private schools. Smaller families like those of nuclear and single parents where the average number of children is about 2 , their children attend either mission schools or lay private schools. Therefore where parents send their children to school significantly depend on their family type (The dependence is not significant (chi2 $=56,79$, ddl $=15$, I$\mathrm{P}=>99,99 \%)$ 


\section{CONFLICT FREQUENCY AND CAUSES IN FAMILY}

Dependent, single parents and single people clash on a daily basis probably because they are not living in any legal relationship. The main sources of clashes in their families is poverty because they have the highest number of persons who live below the poverty-line and as a result find it difficult participating in the main values of the societies: they have poor feeding habits, hardly own homes and rent very cheap houses with limited qualities. Those whose families have conflict on a weekly basis are those having nuclear and polygnous families. The nuclear family has the highest number of persons above the poverty-line and just like the polygnous family, they have a better feeding habit as compare to the other family types which reduces conflict in their family.

People who significantly have more peaceful families are those with extended family because they significantly clash on a monthly basis because they rely on other members of their society to resolve their conflict.

However, there is a very significant relationship between family types and conflict (chi2 $=54,69$, ddl $=25, \mathrm{I}-\mathrm{P}=99,95 \%$ )

About $74.25 \%$ of people have conflict in their families because of poverty and problem of finance. About $71.42 \%, 61.53 \%, 67.41 \%, 94.87 \%, 58.33 \%$, and $100 \%$ of dependent persons, those who have nuclear and extended families, are single parents, have polygnous families and are single persons have conflicts in their families because of poverty and finance. Those whom poverty affects the more are single parents and single people as well as dependent people, that is why their members clash on a daily basis in their relationship and they are unable to formalize their relationships.

Therefore if people earn more money, there will be less conflicts in their families. Other very insignificant causes are misunderstanding of the future or projects of the future (16.83), infidelity (2\%), household management problems (2\%) and other problems $(4.45 \%)$.

\section{CONCLUSION}

The residents of the city of Douala tend to prefer nuclear family as their income rises and as income decreases people tend to use extended family as a survival means. However, dependent persons (make up only $3.5 \%$ of the population and also consist of older persons) and those with nuclear families have the highest number of persons who earn above the poverty-line while single parents have the highest number of persons below the poverty-line.

Basing on the four aspects which the residents of Douala consider as appropriate feeding, we the nuclear family has a better feeding habit discovered that the nuclear family has a better feeding habit because they significantly eat three to four times per day, consume a variety meal daily, fortnightly and occasionally, take enough fruits and vegetables daily and monthly and a balanced diet daily and monthly. Equally, polygamous family members who do not earn much have better feeding habits than extended family members and single parents: they feed thrice per day, vary their meals and significantly eat enough vegetables and fruits daily and fortnightly and balanced diet daily, fortnightly and occasionally.

Dependent people who earn better than polygnous family do not feed better than them because they eat thrice per day, significantly vary their meals daily and fortnightly, eat enough fruits and vegetables weekly and yearly and a balanced diet daily and occasionally. Extended family members, single parents and single people have poor feeding habits. Single parents significantly eat twice per day, vary their meals daily and yearly, eat enough fruits and vegetables weekly and yearly and a balanced diet daily and weekly which is better than that of extended family and single people do not significantly consume variety of meals, enough fruits and vegetables and a balanced diet daily. Apart from the variety of meals, there is a significant relationship between family type and feeding habits.

Those who have smaller family sizes such as dependent people and single parent tend to significantly use formal methods of treatment of illnesses while families with large family size tend to use other methods except the nuclear family. Polygnous and extended families are very unstable in their health seeking behavior because they significantly use all the methods.

The extended family enjoy more domestic comfort than the other family types: they do not only significantly own and rent expensive and quality homes but also have more durable goods. They hardly own homes near stagnant water. They are followed by those who have nuclear families who equally significantly own and rent expensive homes but their homes have fewer qualities as compared to that of the extended family and they possess very limited durable goods. Although dependent people hardly own and rent expensive homes, they have more durable goods and high quality homes because they dependent on others. Polygnous families own and rent averagely expensive houses and their homes are not of high quality and they possess very limited number of durable goods.

Those who suffer the most are single people and single parents. However, single people slightly have more domestic comfort than single parents: they own and rent better houses than those of single parents 
and they significantly possess few or no durable goods.

\section{REFERENCES}

Aerts, J., Denis C, Javier H, Guy de Monchy, and Francois R., 2000. L'Economie Camerounise un Espoir Evanoui. Boulevard Arago: Edition KARTHALA.

Baye, Francis. 2004. "Investigating the Growth and Redistribution Effects of Poverty in Cameroon Development Policy Research (Unit DPRW)." University of Cape Town: Collins Publisher.

Baca Z. M, and Eitzen D.,1993. Diversity in Families. New York: Harper Collins College Publisher Browne, K., 2011. Introduction to Sociology

Culliney M, Tina $\mathrm{H}$ and Stephen M., 2014. "Family Structure and Poverty in the UK: An Evidence and Policy Review Report to Joseph Rowtree Foundation University of Lincoln

Deaton A., 2013. Health, Income and Inequality. National Bureau of Economic Research

Emerson E., Hilary G., and Chris H., 2006 Household Income and Health Statuse in Children and Adolescents.

European Journal of Public Health, Volume 16, Issue 4 page $354-360$

Eurostat 2010 Europe Commission's Consumer Survey Gardiner, K and Millar, J., 2006. How Low-paid Employees avoid Poverty: An analysis by Family Type and Household Structure. Journal of Social Policy University of Bath.

Hunt G., Adam F., Kathleen M., and Molly N., 2001. Food in the Family: Bringing Young People Back in National Center for Biotechnology Information U.S. National Library of medicine, Rockville Pike
Long G., 2018 Financial Crisis still seems like only Yesterday for Single Women: Conversation USA, University of the Witwatersrand

Irwin G., Watson D., and Sara M., 1986 Family Structure, Poverty and the Underclass Contemporary Urban Conditions Workshop

Nyanseor S., 2018. Polygyny is already a Practice The Perspective Atlanta Georgia

Pierre B., and Yves G., 2013. Child Health in the UK, Journal of Health Economics Vol 32 Issue 4 (715-727)

Nanche, R., 2007a. "Urban Poverty in Cameroon. The Case of Douala." Diploma of Advanced Studies (DEA) diss., University of Douala, Cameroon.

Robert, N. 2014. "Gender Difference and Poverty in the City of Douala". Journal of International Women's Studies, Bridgewater State University 15(2): 227-240.

Rouband, F. 1994. "Le Marché du Travail à Yaoundé 1983-1993: La Décennie Perdu Revue Tier Monde." Tome 35 140:751-78

Sachs, J., 2015. The Age of Sustainable Development Columbia University Press New York

Savage J., Jennifer F. and Leam B., 2008. Parental Influence on Eating Behaviour National Center for Biotechnology Information U.S. National Library of medicine, Rockville Pike

Phipps Su An A., 1991 Family Systems Functioning, Family Health Roles, and Utilisation of Physical health Services Lifestyle: Family and Economics Issues 12(1)

Polygamy.com 2015. Polygamy in Africa Dubai UAE

Wolff Edward 2008. Poverty and Income distribution Blackwell Publishing, Hong Kong 